INTERNATIONAL JOURNAL OF RESEARCHES IN BIOSCIENCES, AGRICULTURE AND TECHNOLOGY (C) VISHWASHANTI MULTIPURPOSE SOCIETY (Global Peace Multipurpose Society) R. No. MH-659/13(N) www.vmsindia.org

\title{
WATER RESOURCE AND ENVIRONMENT: OVERVIEW OF AKOLE TAHSIL (M.S, INDIA)
}

\section{P. H. Mhaske}

Department of Geography, Shri. Dnyaneshwar Mahavidyalaya, Newasa, Tal. Newasa, Dist. A. Nagar.

\begin{abstract}
:
Water has been prioritized to be the most crucial resource. Agricultural uses almost $85 \%$ of the total water available in the country. By 2020 we would need about $29 \%$ more water for agriculture whereas water availability is likely to be reduced by $12 \%$. Therefore, not only sustainable development of potential sources of water, but also to augment, conserve and manage these resources through improvement in water storage, conveyance, application and crop-water-use efficiencies, without detriment to environment and natural resource base is imperative, hence enhanced effort and support is needed. Next to water, nutrients are an important input for guiding sustainable growth of agriculture. By 2050, the world's human population is expected to be increase almost by $75 \%$ of the present population. With increasing population, especially in the developing countries, the demand for food and fuel has grown alarmingly. At the same time, changing economic and social conditions have undermined or destroyed traditional system of land resources management. The result has been massive soil degradation on a world scale, though losses of plant nutrients and organic matter, erosion, build up of salinity and damage to soils structure. This has upset or destroyed natural ecosystems and modified or eliminated natural populations of flora and fauna.

Keywords: Environmental Conditions, Water resources, Climatic Condition, Changed economic and social condition.
\end{abstract}

\section{Introduction:}

The western part of the study area in Ahmednagar District is endowed with great natural scenery. The environment development corporation sanctioned Rs. 15 corers. In this area has great tourism potential as it has unique diversification in cultural as well as geographical variations and this will differently attract tourists visiting this area. Till today, in the field of development in this area, none of the geographers has done any research work e.g. cultural, historical, geographical, environmental, tourism, botanical and zoological, economical etc. It is mountainous region (Sahyadri Ghat) with full of natural beauty, wild animals and birds as well as waterfalls. The local area is associated with 'Adivasi' people (ST) such as Thakar, Warli, Katkari, Mahadev-koli etc. and their life style is different from the non-tribal people. Tahsil is also covered by co-operative sugar factory, dairy milk, rice mills, banks and various co-operatives thrive here. The economy of the tahsil is driven mainly by agriculture of sugarcane, rice, horticulture, floriculture and various major cash crop of the study area. Wilson reservoir (Bhandardara), Nilwande reservoir and Adhala reservoir are the major surface water bodies and a large number of Small tanks or reservoirs have been delineated most of which are minor irrigation projects or peculation tanks available.

\section{Objectives:}

1. To study environmental conditions and water resources.

2. To study the Climatic Condition.

\section{Study Area:}

Akole Tahsil is located at western part of Ahmednagar District, in the state of Maharashtra. It is well surrounded with the mountainous of Sahyadries, extends between $19015^{\prime} 14^{\prime \prime}$ and $19044^{\prime}$ 59" North Latitude and $73^{\circ} 37^{\prime} 00$ " to 740 07' 24" East Longitudes, covering an area of 1, 50,508 hector (Map No.1). Pravara, Mula, Adhala and Mhalungi are important rivers, rises in different places of study area. The Highest Peak of Kalsubai (5427 feet) in the Sahyadris with a mean annual rainfall of about $508.9 \mathrm{~mm}$. lies in the study area.

Area under forest in 41,698 hectors. Total Villages 191, population 2, 91,950 (Census 2011), literacy $75.85 \%$ and one of which 1 , 39,730 (ST) Tribal people in this area. The climate of the tahsil is hot and dry. It is characterized by a hot summer and general dryness except during the south-west monsoon season in India.

\section{Methodology:}

The study area include objects prepared with the help of Arc GIS 10.1, Arc View 3.32 and $\mathrm{RS}$ analysis Ilwis 3.3 software packages thematic maps related to study area was 
prepared by using Survey of India Toposheet of 1: 50000 scale as the raster maps.

\section{Discussion:}

The population in this region depends on natural resources and collection of forest products. The primary source of water for agriculture production for most of the world is rainfall. Before rain strikes the earth's surface, there is some evaporation in the atmosphere. This amount is never measured, but it increases air humidity, lowers the temperature and so reduces evaporations from field crops. Vapor may also be blown away by winds to the surrounding area.

\subsection{Climatic Condition:}

Climate is the most effective factor in soil formation and its fertility. Bhandardara is hill station in the study area. In the winter season which starts from November to February, the air is dry and invigorating. The period from March to the first week of June is the hot season. But in some parts of hill ranges in the study area. The temperature is slightly cool in this season. It is followed by the south-west monsoon season which lasts till the end of September, October and November constitute the post-monsoon or the retreating south-west monsoon season.

\subsection{Average Rainfall:}

The primary source of water for agriculture production for most of the world is rainfall. The hilly region receives more rainfall e.g. Ghatghar, Ratanwadi etc. Very high rainfall which ranges from 1500 to $3000 \mathrm{~mm}$ and mostly covered by deciduous or semi deciduous forests, about $50 \%$ of the geographical area is under forest. Year 1990-91 to 2010-11 actual rainfall situations in the study area shows in the following fig no. 1 .

\subsection{Methods of Irrigation:}

The traditional methods of irrigation such as flooding check basin and border irrigation result in poor conveyance and porous soils. Hence, efficient water application methods such as furrow, sprinkler and drip irrigations need to be recommended to minimize wastage of stored water and to bring more area under command (Chart 1).
Irrigation is indispensable to Indian agriculture. Agriculture needs a regular supply of water by irrigation. Irrigation is available from various sources e.g. Wells and Tube-wells irrigation, Tank irrigation, Canal irrigation, Inundation canals, Perennial canals. The important sources available in the tahsil are canal, dams, rivers, wells, bores, tanks, lifts and other irrigation Map no.2.

\subsubsection{Sources of Irrigation:}

At present the Dam irrigation system is confined only to the north east (Adhala dam) and central part (Bhandardara and Nilwande dam), the River, Well and Bore irrigation is widespread to the north (Mhalungi and Adhala river basin), central part (Pravara river basin) and south part (Mula river basin), Tank irrigation is north central and south part, the pre-ponderance of lift irrigation is Mula river basin in the tahsil Map No.2.

\section{LOCATION MAP}
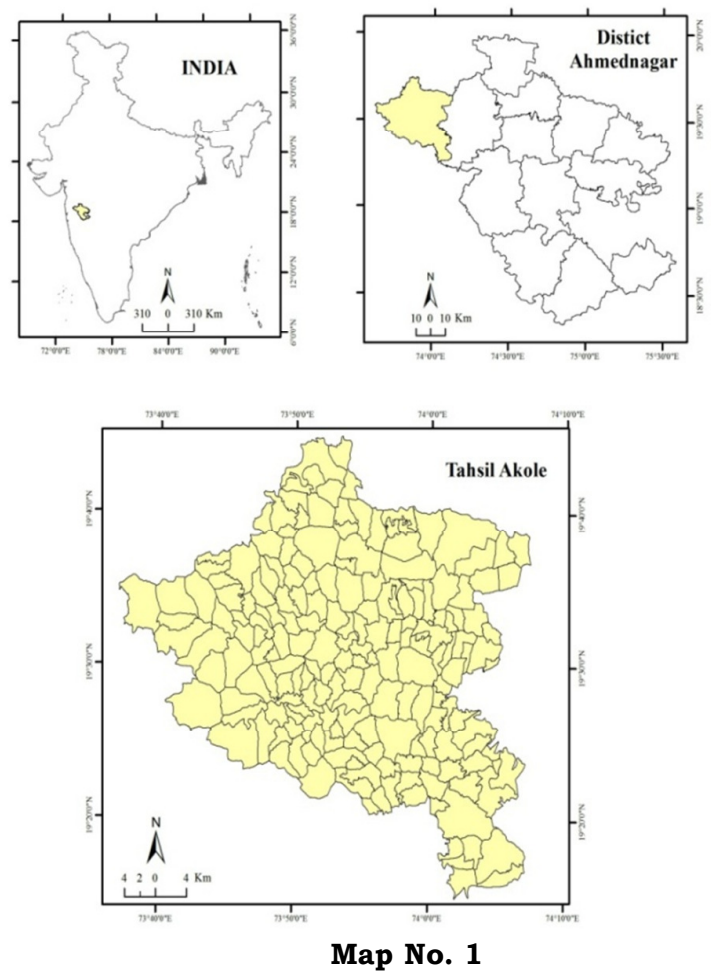

Chart 1 Methods of Irrigation

\section{A) Surface Methods}

1. Check Basin and Border Strip Irrigation

2. Furrow Irrigation

3. Raised bed Planting System

4. Surge Flow Irrigation
B) Pressurized Irrigation Systems (Localized Irrigation)

1. Sprinkler Irrigation

2. Drip Irrigation

3. Rain guns

4. Micro- Sprinkler 

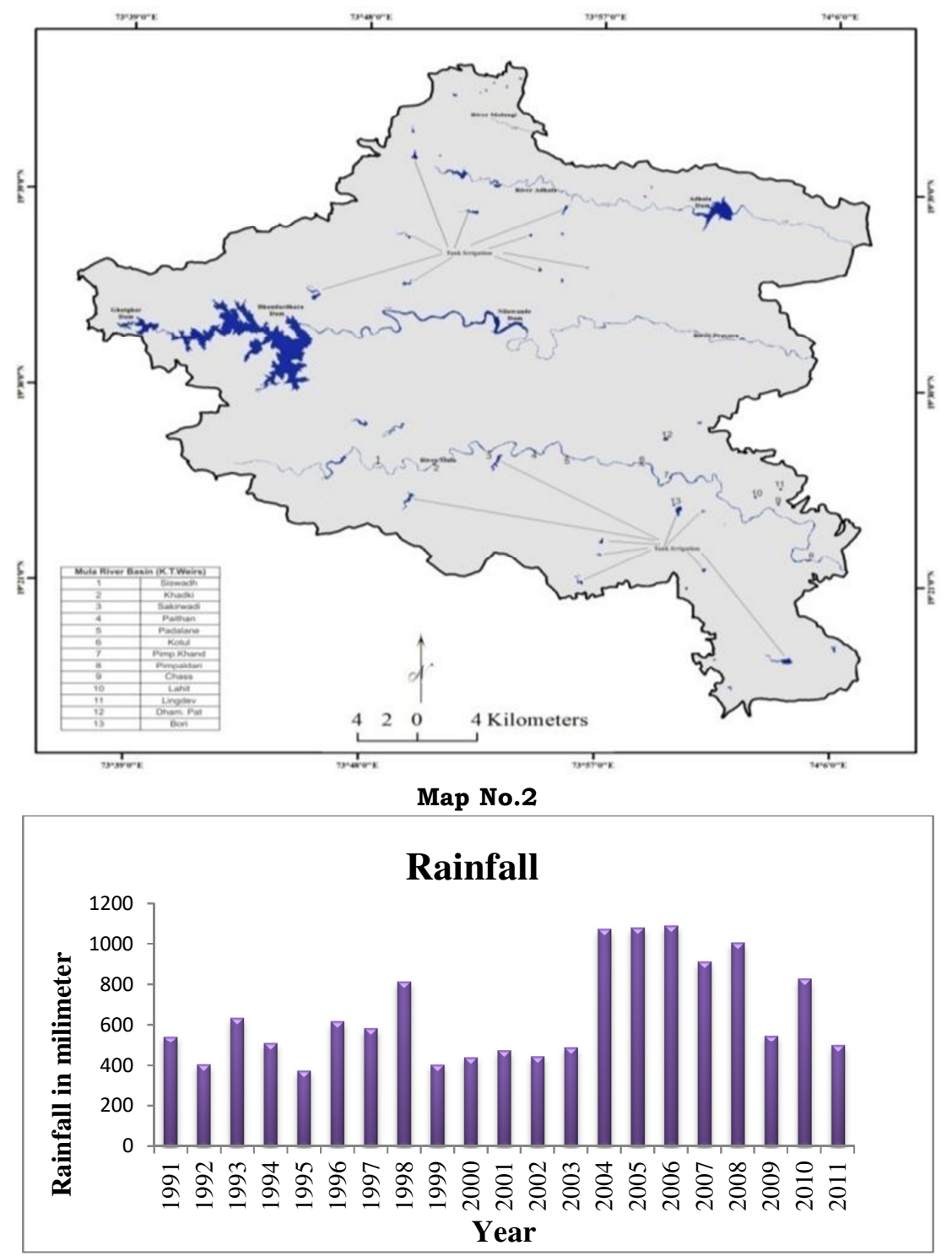

Figure- 1

\section{Conclusion:}

The physical landscape of the region is marked by the mountain and hill ranges, river plains and undulating topography of plateaus in the study area. Sahyadri ranges are well defined by the watershed and available water in various dams. About $80 \%$ population depends directly upon land middle and eastern part of the Akole tahsil, state of Maharashtra, India, is mainly use of the agricultural land and converted into residential and other uses for the growth and development of the facilities. Farmers have adopt modern technology i.e. fruits and vegetables drip irrigation facility, variety seeds material, increasing use by composting biomass, improved planting technology and micro irrigation systems, crop loans, good network of transports and markets, agricultural advisory centers and also available facilities in the study area. Normally, groundwater and surface water are used for irrigation and when water available in these sources is taken away artificially by flowing it for supplying water in required quantity to crops, it is called irrigation. Ground water has emerged as the prime source of drinking and irrigation. Above 90\%, present ground water withdrawal is being used for irrigation purpose thus contributing largely in food security of the study area. Various types of irrigation techniques differ in now the water obtained from the source is distributed within the study area. In general, the goal is to supply the entire field uniformly with water, so that each plant has the amount of water it needs, neither too much nor too little. 


\section{References:}

Ahmednagar District Censes Hand book (1991): 'Series 14, Part xii A and B', Govt. Central Press, Mumbai (MS).

Handbook of Agriculture (2011): Indian Council of Agricultural Research (ICAR $6^{\text {th }}$ Edition Revised), Directorate of Knowledge Management in Agriculture, New Delhi.

Pooja Kashyap (2010): 'Irrigated Agriculture', Oxford Book Company, New Delhi.
Report Official Information (2011): 'Bhandardara Dam', Shendi, Akole.

Socio-Economic Abstract of Ahmednagar District (2011).

Vivek Sharma (1999): 'Tourism in India', Jaipur Publication, New Delhi.

India (2014): 'Abstract of India', Arihant publications (India) ltd, Meera. 